\title{
Calcium and vitamin D metabolism among patients with excess of weight of a docent clinic in Salvador Bahia Brazil.
}

RODRIGUES, J. N.; SCHLEU, M. F.; SILVA, MARIA DE LOURDES LIMA SOUZA E.

Topic: Calcium and vitamin D metabolism

\section{INTRODUCTION}

Hypovitaminosis $D$ is a biochemical change with high prevalence among the population, especially in obese patients. Its function more known relates to bones metabolism, although recently, many functions have been described.

\section{OBJECTIVES}

Describe the prevalence of vitamin $D$ deficiency and evaluate calcium, phosphorus and parathormone metabolism between women with excess of weight followed in an obesity clinic of reference in Salvador-BA.

\section{METHODS}

A descriptive cross-sectional study, which included women over 18 years old with body mass index (BMI) equal or superior of $25 \mathrm{~kg} / \mathrm{m}^{2}$. Anthropometric measurements were obtained: weight, height, BMI, waist circumference, hip circumference; presence of hypertension and / or metabolic syndrome were obtained by analysing the charts of patients in the study. The criteria for diagnosing hypovitaminosis $D$ was established according to The Brazilian Society of Endocrinology and Metabology - levels $\leq 20 \mathrm{ng} / \mathrm{dL}$ means deficiency, 21-29ng/dL are considered insufficiency and levels between $30 \mathrm{ng} / \mathrm{dL}$ and $100 \mathrm{ng} / \mathrm{dL}$ are normal(1).

\section{RESULTS}

Table 1. Anthropometric profile of the patients in study. Bahia, 2015.

\begin{tabular}{c|c|}
\hline & Average \\
\hline Age $($ years $)$ & $43.1 \pm 11.6$ \\
\hline IMC $\left(\mathrm{kg} / \mathrm{m}^{2}\right)$ & $37.1 \pm 6.5$ \\
\hline Abdominal circumference $(\mathrm{cm})$ & $109.3 \pm 13.1$ \\
Waist / hip ratio & $0.86 \pm 0.09$ \\
\hline
\end{tabular}

Bahiana School of Medicine and Public Health, Medical Science
Department Obesity clinics of the Docent Care Clinics of Bahia (ADAB)
The prevalence of obesity was $89.3 \% ; 59 \%$ of the population were hypertensive and $20 \%$ diabetics. The mean of the level of vitamin $D$ was $23.5 \pm 6 \mathrm{ng} / \mathrm{dL}$.

Table 2: Profile of the level os the variables related to bone metabolismo in the group of overweight and obese patients. Bahia, 2015.

\begin{tabular}{|c|c|c|c|}
\hline Variable & Overweight & Obesity & P value \\
\hline $\begin{array}{c}\text { Vitamin D } \\
(\mathrm{ng} / \mathrm{dL})\end{array}$ & $26.89 \pm 7.47$ & $23.13 \pm 5.70$ & 0.100 \\
\hline $\mathrm{PTH}(\mathrm{mg} / \mathrm{dL})$ & $41.69[26.4-37.4]$ & $63.32[26.4-37.4]$ & 0.030 \\
\hline $\begin{array}{c}\text { Calcium } \\
(\mathrm{mg} / \mathrm{dL})\end{array}$ & $10.13 \pm 0.8$ & $9.45 \pm 0.70$ & 0.052 \\
\hline $\begin{array}{c}\text { Phosphorus } \\
(\mathrm{mg} / \mathrm{dL})\end{array}$ & $3.88 \pm 0.36$ & $3.86 \pm 0.51$ & 0.840 \\
\hline Source: $\mathrm{ADAB}$ & & & \\
\hline
\end{tabular}

Graph 1: Profile of vitamin $D$ level between the patients in study. Bahia, 2015.

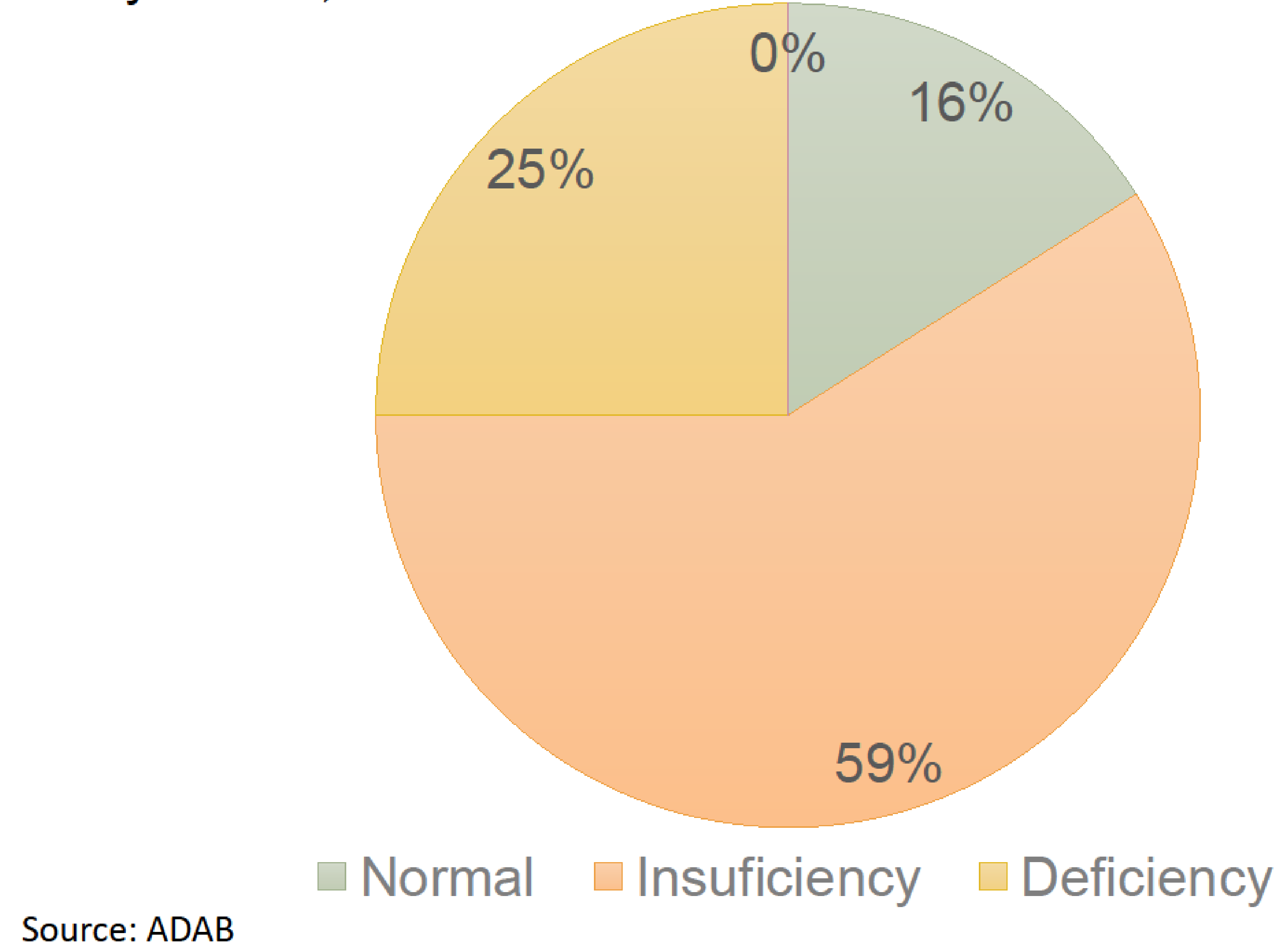

It was observed an inverse correlation between BMI and the levels of vitamin $D(p=0.04)$.

\section{CONCLUSIONS}

The prevalence of hypovitaminosis among patients with excess of weight is higher than in the general population. There is an inverse correlation between the levels of vitamin D and BMI.

\section{REFERENCES}

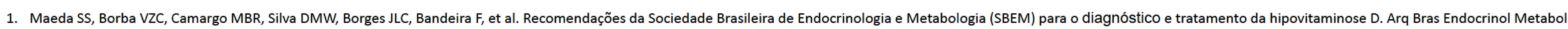
[Internet]. $2014 \mathrm{Jul}$ [cited 2014 Oct 1];58(5):411-33. Available from: http://www.scielo.br/scielo.php?script=sci arttext\&pid=S0004-27302014000500411\&lng=pt\&nrm=iso\&tlng=en 